УДК 629.4.027.4

СИСТЕМА КОНТРОЛЮ ЯКОСТІ ТЕХНОЛОГІЧНИХ ПАРАМЕТРІВ РЕМОНТУ КОЛІСНИХ ПАР ПАСАЖИРСЬКИХ ВАГОНІВ

Канд. техн. наук В.М. Петухов, магістранти О.О. Гайворонська, М.А. Суханенко

СИСТЕМА КОНТРОЛЯ КАЧЕСТВА ТЕХНОЛОГИЧЕСКИХ ПАРАМЕТРОВ РЕМОНТА КОЛЕСНЫХ ПАР ПАССАЖИРСКИХ ВАГОНОВ

Канд. техн. наук В.М. Петухов, магистранты А.А. Гайворонская, М.А. Суханенко

\title{
THE QUALITY CONTROL SYSTEM OF TECHNOLOGICAL PARAMETERS OF THE REPAIR OF WHEELSETS OF PASSENGER CARS
}

Cand. of techn. sciences V. Petukhov, master student A. Gaivoronska, M. Sukhanenko

Проведено аналіз системи контролю технологічних чинників $і$ параметрів якості ремонту колісних пар пасажсирських вагонів при технологічному процесі. На основі цьвого запропоновано математичну модель процесу контролю якості ремонту колісної пари, яка дозволяє одержати комплексну інформацію про ї̈ життєвий цикл, наводить характеристику зміни стану всіх ї̈ параметрів і адекватно відображує інформачію про ї̈ технічний стан за будь-який період часу.

Ключові слова: пасажирський вагон, колісна пара, якість, технологічний процес, система, обладнання, технологія, параметр .

Проведен анализ системы контроля технологических факторов и параметров качества ремонта колесных пар пассажирских вагонов при технологическом процессе. На основе этого предложена математическая модель процесса контроля качества ремонта колесной пары, которая позволяет получить комплексную информацию о ее жизненном цииле, приводит характеристику 
изменения состояния всех ее параметров и адекватно отражает информачию о ее техническом состояние за любой период времени.

Ключеые слова: пассажсирский вагон, колесная пара, качество, технологический процесс, система, оборудование, технология, параметр.

The analysis of control systems of technological factors and quality parameters of repair of wheelsets of passenger cars in the process. Based on this mathematical model of the process of quality control for repair of wheel pairs, which allows to obtain comprehensive information about its life cycle, causes characteristic changes of the status of all of its parameters and adequately reflects information about technical condition for any period of time.

Keywords: passenger car, pair of wheels, quality, process, system, equipment, technology, option.

Вступ. Основною метою діяльності будьякого підприємства $є$ одержання максимального прибутку. Специфіка сучасного ринку й умови твердої конкуренції, характерні для сучасного періоду, змушують безупинно шукати шляхи підвищення рентабельності виробництва, удосконалення процесу управління й планування.

У ринковій економіці проблема якості $є$ найважливішим чинником підвищення економічної, соціальної й екологічної безпеки. Якість - комплексне поняття, що характеризує ефективність всіх сторін діяльності: розроблення стратегії, організація виробництва й ін. Найважливішою складовою всієї системи якості є якість продукції. Міжнародна організація зі стандартизації визначає якість як сукупність властивостей і характеристик продукції, які надають їй здатність задовольняти обумовлені або передбачувані потреби [1].

Аналіз останніх досліджень i публікацій. На сьогоднішній день у вітчизняній і закордонній науці склався ряд основних концепцій і методичних підходів до вивчення проблем якості технології ремонту вузлів. Роботи відомих учених П.Л. Чебишева та А.М. Ляпунова $€$ теоретичною основою вибіркового контролю якості. Великий внесок у розроблення систем управління якістю, що застосовуються в наш час, зробили вітчизняні вчені І.Г. Венецький та А.М. Довжин, а також закордонні американські вчені У.А. Шухарт, Е. Деминг, А. Фейгенбаум, які запропонували математичні моделі та підходи для підвищення якості продукції технологічних процесів [2].

$$
\text { Визначення мети та задачі }
$$
дослідження. Метою роботи є вибір критеріїв оптимізації та розроблення математичної моделі для підвищення ефективності технологічного процесу ремонтну колісних пар пасажирських вагонів.
До основних завдань технологічних процесів, які необхідно дослідити на вагоноремонтних підприємствах, належать:

- загальне підвищення ефективності роботи колісних цехів (дільниць);

- підвищення якості ремонту колісних пар пасажирських вагонів;

- зниження трудомісткості й собівартості ремонту колісних пар пасажирських вагонів;

- скорочення тривалості технологічного циклу.

Основна частина дослідження. При реконструкції й модернізації існуючих колісних цехів 3 різною програмою виникає завдання вибору раціональної структури й рівня організації технологічного процесу. Структура являє собою комплекс взаємозалежних, розташованих в обумовленій технологічним процесом послідовності операцій, що виконуються за допомогою основного й допоміжного обладнання. Завдання вибору структури зводиться до встановлення типів обладнання, рівня організації й управління виробництвом, ступеня концентрації (диференціації) технології при заданій програмі й мінімальних наведених витратах на ремонт $\mathrm{i}$ формування колісних пар. Найбільш раціональна організація технологічної структури цехів дозволяє вирішити завдання 3 урахуванням різної номенклатури колісних пар, що ремонтуються, за типами розходження цехів, за рівнем механізації, автоматизації й управління виробничим процесом i 3 застосуванням при ремонті й формуванні колісних пар різного за своїми параметрами i продуктивністю обладнання [3, 8].

Оптимізація технологічної структури колісних цехів дозволяє здійснити вибір технологічних маршрутів, рівня, організації виробництва, найбільш раціонального за своїми характеристиками i продуктивністю 
обладнання, установити оптимальні доробки між операціями й інші характеристики цехів залежно від виробничої програми. Для ефективного використання виробничих потужностей необхідно враховувати такі принципи галузевої організації ремонту колісних пар, як раціональна концентрація й спеціалізація виробництва.

Високопродуктивні автоматизовані колісні цехи необхідно комплектувати залежно від необхідної виробничої потужності 3 окремих, відносно автономних, але пов'язаних між собою загальним управлінням ліній. Лінії, як виробничі модулі, створюють умови для комплектування колісних цехів із заданою виробничою потужністю. До основних ліній варто віднести лінії демонтажу й монтажу роликових букс, вхідного й вихідного контролю, відновлення профілю поверхонь кочення коліс і шийок осей колісних пар, розформування, обробки підматочинних частин осі, формування колісних пар, фарбування і сушіння.

Iз зазначених модулів можна комплектувати окремо лінії ремонту без заміни й 3 заміною елементів колісних пар. Так, наприклад, лінія ремонту колісних пар без заміни елементів комплектується 3 модулів миття, вхідного контролю (дефектоскопії), відновлення профілю поверхонь кочення коліс $\mathrm{i}$ шийок осей колісних пар. Потокова лінія ремонту колісних пар без заміни елементів забезпечує економічну високопродуктивну обробку; продуктивність іiї становить близько 60 колісних пар у зміну. Поточно-механізовані лінії ремонту колісних пар із примусовим тактом дисциплінують виробництво й сприяють кращому використанню обладнання $[6,9,10]$.

Варіюючи кількість ліній і виробничих модулів на ділянках, можна компонувати цехи 3 різною виробничою потужністю за значенням i видами ремонту колісних пар. Скомплектовані з окремих типових виробничих модулів, що містять у єдності виконавчі лінії, контрольні й транспортні засоби, колісні цехи повинні бути об'єднані єдиним управлінням. Такий принцип агрегатного компонування високопродуктивних цехів дає можливість організувати випуск типових модулів силами промислових підприємств. При цьому, як показує передовий закордонний і вітчизняний досвід, при створенні високопродуктивних цехів повинен використовуватися комплексний метод, що передбачає рішення всіх технологічних i організаційних аспектів виробничого процесу ремонту колісних пар у іхній сукупності.

При вирішенні даного завдання основні зусилля повинні бути спрямовані на створення системи, що містить чотири основних взаємозалежних комплекси технічних засобів:

- нове спеціалізоване обладнання, оснащене пристроями для його автоматизації;

- технічні засоби для автоматичних вимірювань на технологічних i контрольних операціях;

- засоби для автоматичного транспортування коліс, осей і колісних пар;

- пряме програмне управління технологічним процесом ремонту колісних пар, що реалізовано на основі використання автоматизованих систем управління й контролю і об'єднує всі технічний засоби в єдину систему.

Дана умова $\epsilon$ основою прогресивної технології. Відсутність у виробничій системі цеху хоча 6 одного 3 перелічених чотирьох комплексів призведе до недовикористання інших і до зниження ефективності всієї системи ремонту колісних пар пасажирських вагонів.

Розвиток галузі залізничного транспорту здійснюється шляхом впровадження ресурсозберігаючих технологій i засобів технологічного оснащення виробництва $[3,6]$. Обрана технологія повинна найбільшою мірою відповідати потребам конкретного підприємства, а на стадії проектування технологічних процесів необхідно кількісно оцінити витрати трудових, матеріальних, енергетичних, фінансових і інших ресурсів.

На жаль, у цей час коригування технологічних процесів вагоноремонтних підприємств здійснюється без оцінки їх кількісних показників.

Для вирішення завдання підвищення ефективності ремонтних процесів необхідно обрати критерій оптимізації; розробити математичну модель оптимізуючої системи, а також методи й алгоритми вирішення поставленого завдання.

Основні етапи аналізу й синтезу процесу ремонту колісних пар вагонів наведено на рис. $1[6]$.

На рис. 2 зображено узагальнену принципову схему технологічного процесу ремонту колісних пар пасажирських вагонів. 
Рухомий склад залізниць

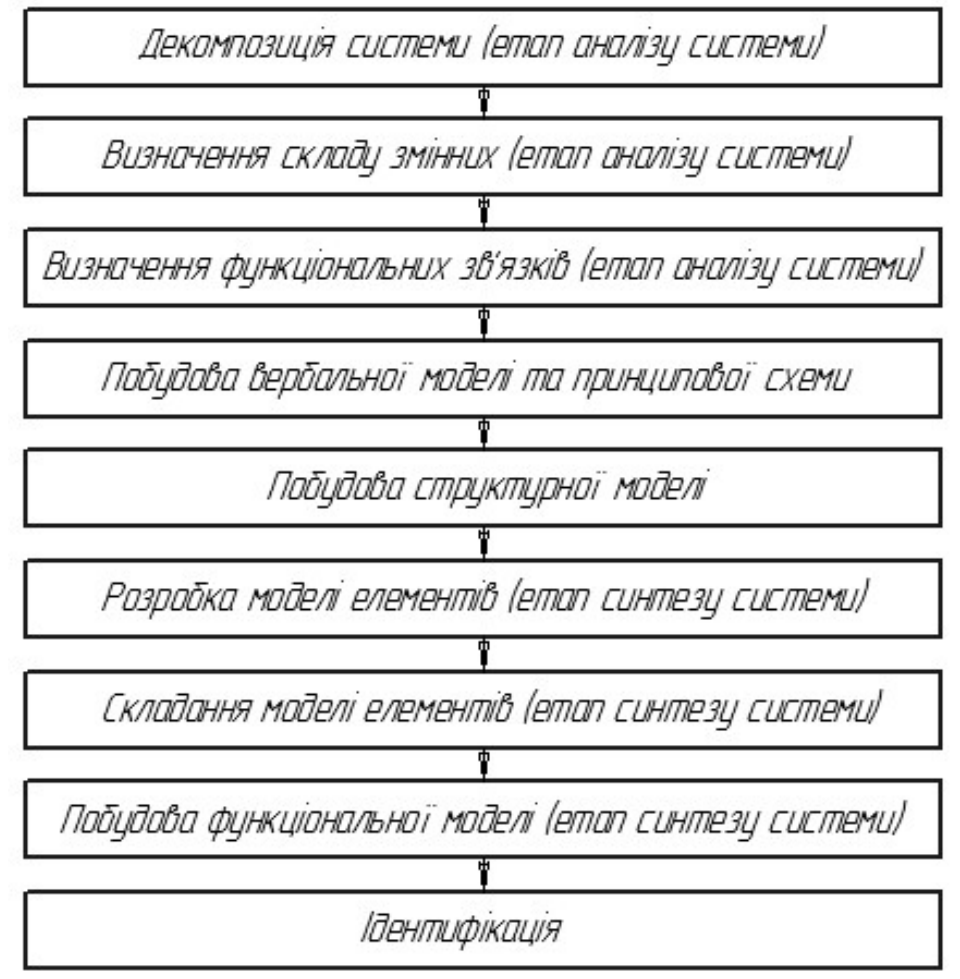

Рис. 1. Етапи аналізу й синтезу процесу ремонту колісних пар вагонів

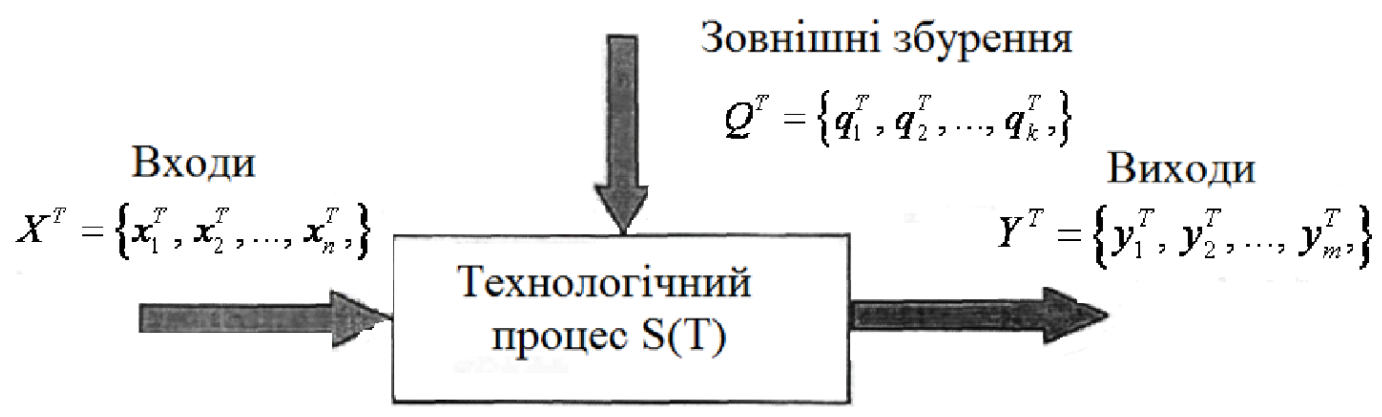

Рис. 2. Узагальнена принципова схема технологічного процесу ремонту пасажирських вагонів

Технологічний процес $S(T)$ (рис. 1) можна описати таким виразом $[4,5,7]$ :

$$
S(T)=\left\{I d n^{T}, \operatorname{Pr} p^{T}, A t r^{T}, X^{T}, Y^{T}, Q^{T}, C^{T}, S t r^{T}\right\}
$$

де $I d n^{T}$ - ідентифікатор системи технологічного процесу ремонту колісних пар;

$\operatorname{Pr} p^{T}$ - мета процесу;

$A t r^{T}$ - загальносистемні атрибути;

$X^{T}=\left\{x_{1}^{T}, x_{2}^{T}, \ldots, x_{n}^{T},\right\}$ - вхідні параметри технологічного процесу, до яких насамперед належать вид ремонту, тип колісної пари, яка ремонтується, ऑii технічний стан, вимоги нормативних документів до відремонтованої колісної пари;

$$
Y^{T}=\left\{y_{1}^{T}, y_{2}^{T}, \ldots, y_{m}^{T},\right\} \quad-\quad \text { вихідні }
$$

характеристики технологічного процесу: 
трудомісткість, тривалість, витрата матеріалів, запчастин, енергетичних ресурсів, собівартість виконання операцій;

$$
Q^{T}=\left\{q_{1}^{T}, q_{2}^{T}, \ldots, q_{k}^{T},\right\} \text { - вплив зовніш- }
$$

нього середовища, у тому числі зміни вимог правил ремонту, поява нових технологій, обладнання й оснащення, постановка в ремонт нових типів колісних пар вагонів;

$$
C^{T}=\left\{C_{1}^{T}, C_{2}^{T}, \ldots, C_{k}^{T},\right\} \text { - внутрішні влас- }
$$

тивості технологічного процесу: комплект засобів технологічного оснащення, кількість і кваліфікація виконавців робіт, цех, дільниця, робоче місце виконання операцій;

$$
S t r^{T}=\left\{T, R^{T}\right\} \text { - структура технологіч- }
$$
ного процесу;

$T$ - елементи процесу, до яких належать всі операції й переходи;

$R^{T}$ - зв'язки між елементами технологічного процесу.

Ідентифікатор системи $\left(\operatorname{Idn} n^{T}\right)$ являє собою сукупність двох полів: <позначення технологічного процесу> i <найменування технологічного =процесу>, наприклад: $I d n^{T}=\prec 10.00001 \succ \quad<$ Дефектоскопія колісної пари>.

Одне 3 основних завдань технологічних процесів вагоноремонтних підприємствах — це підвищення ефективності роботи підприємства і підвищення якості ремонту вагонів $[6,8,10]$.

Функціональне призначення технологічних процесів вагоноремонтного підприємства полягає в перетворенні значень параметрів, які характеризують технічний стан колісних пар вагонів, що надходять у ремонт.

Як входи технологічного процесу вагоноремонтного підприємства варто розглядати, насамперед, сукупність значень параметрів, що характеризують технічний стан колісних пар вагонів, що надходять у ремонт, а як виходи - сукупність значень параметрів, що характеризують технічний стан колісних пар вагонів, що виходять із ремонту.

Вплив зовнішнього середовища на технологічний процес можуть мати випадковий характер і проявлятися в зміні матеріальних, енергетичних i iнформаційних процесів взаємодії. Для технологічних систем вагоноремонтних підприємств зовнішніми чинниками можуть бути:

- зміни виробничої програми;

- стан вагонів i їхніх вузлів, що надходять у ремонт;

- нові технології й засоби технологічного оснащення;

- зміни правил ремонту й технічного обслуговування;

- стан технологічного обладнання.

Внутрішні властивості $C^{T}$ і структура $S t r^{T}$ технологічного процесу на загальному рівні моделювання описуються перерахуванням елементів, їх властивостей i зв'язків. Технологічний процес варто розглядати як систему, що складається 3 двох рівнів технологічна операція й технологічний перехід.

У загальному випадку до властивостей елементів системи будь-якого рівня варто відносити безліч значень параметрів технологічних процесів, операцій і переходів:

- засоби технологічного оснащення (обладнання, пристосування, інструмент);

- професіоналізм виконавців i ïx кількість;

- основний, допоміжний i підготовчозаключний час;

- витрата матеріалів і запчастин;

- місце проведення робіт (цех, дільниця, робоче місце), а також умови праці; деталей;

- контрольовані параметри вузлів i

- режими обробки колісних пар, які ремонтуються.

На рис. 3 зображена узагальнена структурна схема технологічного процесу ремонту вузлів пасажирських вагонів, що складається 3 двох рівнів $[4,5]$ :

$$
T=\left\{T_{1}, T_{2}\right\},
$$

де $T$ - безліч елементів технологічного процесу;

$T_{1}$ - елементи 1-го рівня (операції технологічного процесу);

$T_{2}$ - елементи 2-го рівня (переходи операцій технологічного процесу), що включають $M_{l}$ - кількість елементів 1-го рівня, $M_{2}$ - кількість елементів 2-го рівня.

Позначимо зв'язки між елементами системи через $R$ : 


$$
R^{T}=\left\{R_{1}^{T}, R_{2}^{T}\right\}
$$

де $R^{T}$ - зв'язки між елементами системи;

$R_{1}^{T}$ - міжрівневі зв'язки елементів на 1-му рівні;

$R_{2}^{T}$ - міжрівневі зв'язки елементів на 2-му рівні, що включають $S_{l}$ - кількість міжрівневих зв'язків елементів на 1-му рівні; $S_{2}$ - кількість міжрівневих зв'язків елементів на 2-му рівні [6-8].

$$
\text { Математична модель структури }
$$
технологічного процесу (реляційна система) може бути подана як

$$
S t r^{T}=T R^{T}
$$

де $T$ - елементи системи (носій моделі);

$$
R^{T} \text { - зв'язки між елементами системи }
$$
(сигнатура моделі), тобто послідовність операцій і переходів.

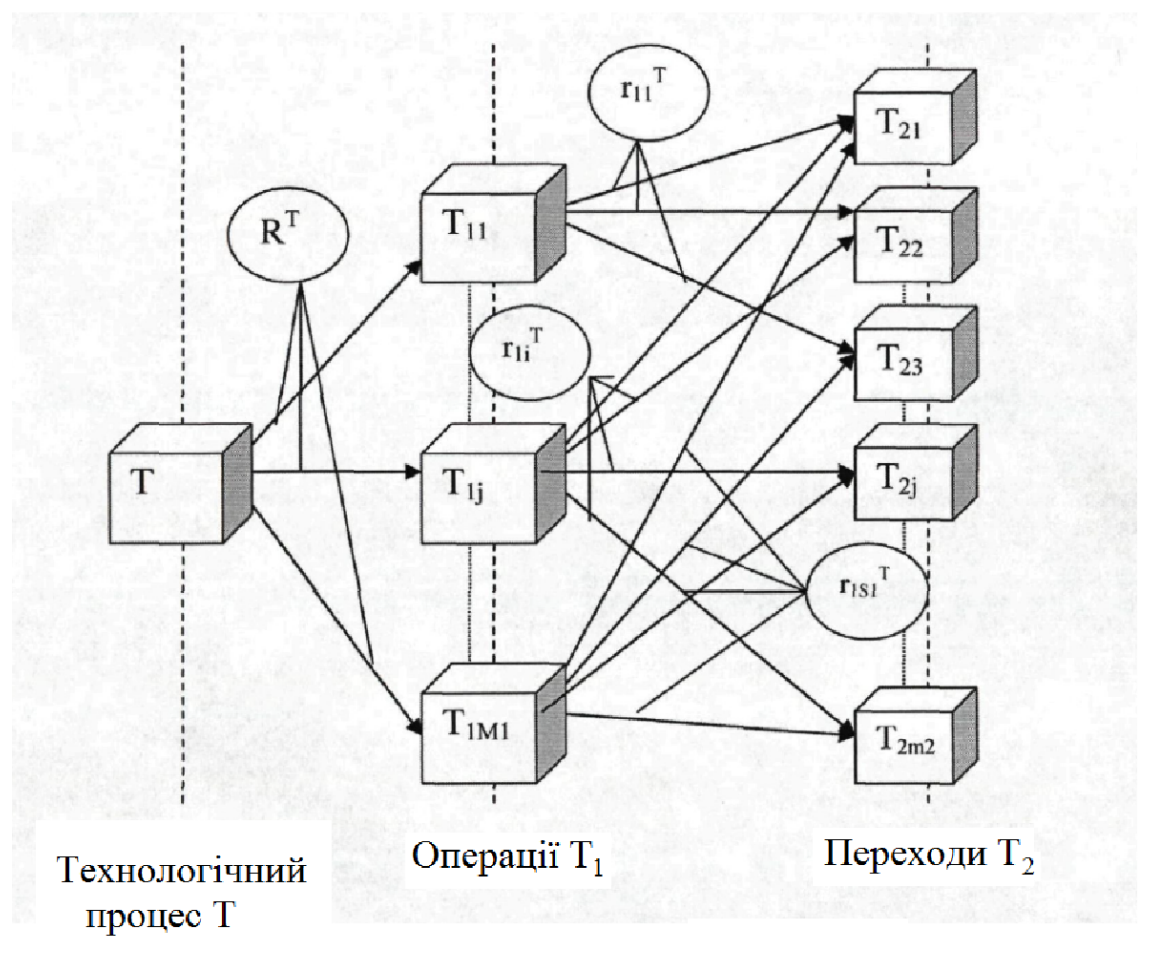

Рис. 3. Узагальнена структурна схема технологічного процесу ремонту колісних пар пасажирських вагонів

Висновок. Вирішено завдання щодо підвищення ефективності ремонту колісних пар вагонів на основі сучасних автоматизованих технологій. Доведено, що використання автоматизованої системи контролю якості ремонту колісних пар дозволяє одержати комплексну інформацію про іiї життєвий цикл, що характеризує зміни стану всіх іiі параметрів, у тому числі окремих частин колісної пари (у випадку заміни елементів) у єдності чинників $і$ умов функціонування процесу i адекватно відображує інформацію про її технічний стан за будь-який період часу.

Наведено методику для визначення показників якості ремонту колісних пар пасажирських вагонів у цехах, дільницях або відділеннях вагоноремонтних підприємств залізничного транспорту, який заснований на кількісній оцінці чинників, що впливають у цілому на якість технологічного процесу ремонту пасажирського вагона. 


\section{Список використаних джерел}

1. Фейгенбаум, А. Контроль качества продукции [Текст]: учебник / сокр. пер. с англ.; А. Фейгенбаум. - М.: Экономика, 1986. - 471 с.

2. Венецкий, И.Г. Теория вероятностей и математическая статистика [Текст]: учебник / И.Г. Венецкий, Г.С. Кильдишев. - М.: Статистика, 1975. -345 с.

3. Головко В.Ф. Інформаційно-технологічне забезпечення технічного обслуговування та ремонту пасажирських вагонів [Текст] / В.Ф. Головко, І.Д. Борзилов // Зб. наук. праць. - Харків: УкрДАЗТ, 2006. - Вип. 76. - С. 131 - 139.

4. Вентцель, Е.С. Теория вероятностей [Текст]: учебник / Е.С. Вентцель, Л.А. Овчарова. - М.: Физматгиз, 1979. - 366 с.

5. Вентцель Е.С. Исследование операций. Задачи, принципы, методология [Текст]: учебник / Е.С. Вентцель. - М.: Наука, 1980. - 551 с.

6. Сергеев, К.А. Проектирование вагонных депо и ремонтных заводов. [Текст]: учеб. пособие / К.А. Сергеев, В.Н. Жданов, О.Ю. Кривич. - М.: РГОТУПС, 2002. - 143 с.

7. Фурцев, А.И. Вагонное хозяйство в условиях реформы транспорта [Текст] / А.И. Фурцев // Вагоны и вагонное хозяйство. - 2004. - Пилотный выпуск. - С. 6-7.

8. Фурцев, А.И. Оперативно-статистическое управление качеством ремонта в вагонных депо [Текст] / А.И. Фурцев, А.З. Венедиктов, М.А. Кованин. // Ремонт, восстановление, модернизация. 2005. - № 8. - С. 40-43.

9. Інструкція з огляду, обстеження, ремонту та формування вагонних колісних пар [Текст]: ЦВЦЛ-0062. - К.: ВД Мануфактура, 2006. - 102 с.

10. Інструкція з експлуатації та ремонту вагонних букс з роликовими підшипниками [Текст]: ЦВ-ЦЛ-0058. - К.: НВП Поліграфсервіс, 2004. - 160 с.

Рецензент д-р техн. наук, професор О.С. Крашенінін

Петухов Вадим Михайлович, канд. техн. наук, доцент, кафедра вагонів, Український державний університет залізничного транспорту. Тел.: (057) 730-10-35.

Гайворонська Олександра Олександрівна, магістрант.

Суханенко Маргарита Андріївна, магістрант.

Petukhov Vadim M., cand. of techn. sciences, docen of chair of cars of Ukrainian state University of railway transport. Tel.: (057) 730-10-35.

Gaivoronskay Alexandra A. master student.

Sukhanenko Margarita A. master student.

Наукова праця здана до друку 18.09.2015 р. 